\title{
Konya'da nadir görülen zoonotik infeksiyon; babesiozis olgu sunumu
}

\section{A rare zoonotic infection in Konya; case report of babesiozis}

\author{
(iD Esma Kepenek Kurt ${ }^{1}$, iD Bahar Kandemir ${ }^{1}$, (iD Erol Handemir ${ }^{2}$, (iD Mehmet Bitirgen ${ }^{1}$ \\ ${ }^{1}$ Necmettin Erbakan Üniversitesi Meram Tıp Fakültesi, Enfeksiyon Hastalıkları ve Klinik Mikrobiyoloji \\ 2İl Sağlık Müdürlüğü Halk Sağlığı Hizmetleri Başkanlığı, Bulaşıcı Hastalıklar Birimi
}

$\ddot{\mathbf{O z}}$

Babesyoz, Babesia adlı bir mikroorganizmanın etken olduğu eritrosit içi kene kaynaklı zoonotik bir infeksiyondur. Ülkemizde sporadik olarak görülmekle birlikte insan babesyozisi konusunda yayınlanmış çok fazla olgu bulunmamaktadır. Bu olguda ateş ve pansitopeni nedeniyle araştırılan, kene teması olmadığı halde periferik kan yaymasında eritrosit içi parazite ait yapılar görülerek, Babesyoz tanısı ile kinin ve klindamisin ile tedavi edilmiş ve tedavinin ikinci gününde ateşi düşüp tam kan sayımı düzelen bir olgu sunulmaktadır.

Anahtar kelimeler; insan, babesyoz, olgu

\begin{abstract}
Babesiosis is tick-borne zoonotic infection caused by Babesia microorganism that settles into erythrocytes. Although it is seen as sporadic in our country, there are not so many cases published on in this subject. In this case, we present a case which was investigated for fever and pancytophenia, and in case of not having tick contact, intra-erythrocythe parasites were seen on the peripheral blood smear and Babesiozis pre-diagnosis and quinine and clindamycin upon Babesiozis prediagnosis, as a result of which the patients's fever decreased and the complete blood count improved on the second day of the treatment.
\end{abstract}

Keywords; human, babesiosis, case

\section{Giriş}

Babesyoz; Babesia cinsinin oluşturduğu, tropik ve subtropikbölgelerde birçok memeli hayvanda nadiren de insanlarda da görülebilen, vektör keneler tarafından taşınan, zoonotik protozoon bir hastalıktır. Hastalık özellikle yaz aylarında vektör kenelerin aktifleşmesiyle birlikte yüksek ateş, anemi, anoreksi, kaşeksi, hemoglobinüri, hipotansif şok ile seyretmekte ve ölümlere neden olabilmektedir (1). Babesyoz, eritrositleri infekte eder (2). Babesia microti, Babesia divergens ve Babesia bovis insan babesyozisinin en s1k etkenleridir (3). Asya, Avrupa, Afrika, Avustralya ve Kuzey Amerika'dan sporadik vakalar bildirilmiştir. (4).Ülkemizde yapılan bir çalışmada Sinop'un kırsal bölgelerinde yaşayan insanlarda, indirekt floresan antikor yöntemiyle bakılan B. microti için Ig G antikor seropozitifliği \%6,23 (17/273) olarak bulunmuştur (5). Sivas'ta yapılan bir çalışmada kene tutunma öyküsü olan 150 insan serumunda indirekt immünofloresan testi (IFAT) yöntemiyle $B$. bovis'e karş1 $\% 5,33$ oranında $\operatorname{IgG}, \% 0,66$ oranında IgM antikor pozitifliği saptanmıştır (6). Türkiye'de sığır babesyozisine neden olan türlerin $B$. bovis, Babesia bigemina ve $B$. divergens olduğu ve bu türlerin bölgelere göre dağ 1 lımlarının değiştiği bildirilmiştir (7). İnsan babesyozisi en sık kene 1sırı̆ğ ile oluşmasına rağmen, kan transfüzyonu, transplasental ya da perinatal bulaş sonucu da ortaya çıkabilir. İnsanlar babesyozisde rastlantısal olarak konaktırlar $(8,9)$.
Ülkemizde babesyoz konusunda yapılan çalışmalar daha çok hayvanlar üzerinde yapılmış olup insanlarda babesyoz nedeniyle tanı konulup tedavi edilen az sayıda olgu sunumu bulunmaktadır. Bu sebeple kliniğimizde teşhis koyduğumuz ve tedavi ettiğimiz bir olguyu bildirmekteyiz.

\section{Olgu}

25 yaşında erkek hasta Mart 2018'de ateş, üşüme, titreme, boyun arka tarafından başlayıp alına doğru yayılan baş ve boyun ağrısı, halsizlik, ishal, bulantı, karın ağrısı şikayetleri ile hastanemiz Enfeksiyon Hastalıkları ve Klinik Mikrobiyoloji polikliniğine başvurdu. Ateş etyolojisini araştırmak için kliniğe yatırılan hastanın gün içinde sürekli olan, ateş düşürücülerle düşmeyen ateşi mevcuttu. Hikayesinde yakın zamanda seyahat, kan transfüzyonu, keneye maruziyet öyküsü yoktu. İshali 3-4/gün olan yarı forme şeklindeydi. Karın ağrısı tüm batında yaygın, aralıklı, yediği gıdalarla ilişkisiz şekildeydi. Fizik muayenesinde bilinci açık, koopere, oryante idi. Vücut 1s1s1 $38.8^{\circ} \mathrm{C}$, nabız 105/dakika, solunum sayıs 22 /dakika, kan basınc $110 / 60 \mathrm{mmHg}$ olarak bulundu. Ense sertliği yoktu. Diğer sistem bulguları normaldi. Kliniğe yatırılan hastanın yapılan tetkiklerinde hemoglobin (Hg);14gr/dL (12.1-17.2), trombosit;95.000/. $\mathrm{mm}^{3}$ (150-

Yazışma Adresi: Esma Kepenek Kurt, Necmettin Erbakan Üniversitesi Meram Tıp Fakültesi, Enfeksiyon Hastalıkları ve Klinik Mikrobiyoloji

E-Posta: esma_kepenek@hotmail.com

Alınma Tarihi: 03.12.2018 / Kabul Tarihi: 08.05.2019 / Yayımlanma Tarihi: 15.06.2021 


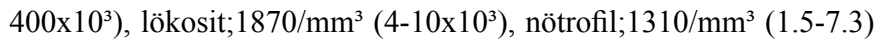
lenfosit; $420 / \mathrm{mm}^{3}$ (0.8-5.5), sedimentasyon (SED): $4 \mathrm{~mm} / \mathrm{s}(0-20), \mathrm{C}$ reaktif protein $(\mathrm{CRP}): 77.2 \mathrm{mg} / \mathrm{L} \quad(0.1-5)$, aspartat amino transferaz (AST);72 1u/L (5-34), alanin amino transferaz (ALT);651u/L (055), laktat dehidrogenaz (LDH);673u/L (125-220) olarak bulundu. Üç sefer bakılan gayta mikroskopisinde lökosit, eritrosit, parazit saptanmadi. Diğer biyokimyasal testler normal değerdeydi. Tam idrar tetkikinde lökosit ve nitrit saptanmadı. Boyun ultrasonografisinde (USG) lenfadenopati saptanmad. Batın USG'sinde karaciğer kraniokaudal uzunluğu $15 \mathrm{~cm}$, dalak uzun aksı $19 \mathrm{~cm}$, parankim ekojeniteleri ve batın içi diğer organlar normal saptandı. Akciğer grafisi normaldi. Hepatitis A, B, C, immün yetmezlik virüsü (HIV), Borrelia IgM ve brusella immuncapture testi negatifti. Ateş etyolojisini araştırmak ve infektif endokardit araştırmak için bakılan transtorasik ekokardiografisinde vejetasyon saptanmadı. Sağlik Bakanlığı Ankara Halk Sağlığı Genel Müdürlüğü Zoonotik ve Vektörel Hastalıklar Daire Başkanlığı labaratuvarına gönderilen kırım kongo kanamalı ateşi (KKKA) polimeraz zincir reaksiyonu (PCR) yöntemi sonucu ve IgM titresi negatif geldi. Hastanın ateşinin sürekli olması üzerine sıtma ön tanısı ile bakılan Giemsa ile boyanan kan yaymalarında eritrosit içi armut şeklinde Babesia sp. merozoit (Şekil 1) formu görülmesi üzerine plasmodium tanısı dışlanarak Babesyozis tanısı konulup intravenöz klindamisin $4 \times 600 \mathrm{mg}$ ve peroral $3 \times 600$ mg kinin sülfat tedavisi başlandı. Tedavinin ikinci gününde hastanın ateşi düştü. Yapılan tetkiklerinde $\mathrm{Hg} ; 13 \mathrm{gr} / \mathrm{dL}$, trombosit;187.000/

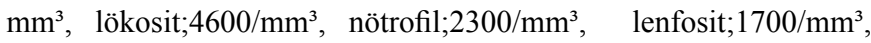
CRP;83.5mg/L, AST;1441u/L, ALT;2381u/L saptandı. Takipte ishal ve karın ağrısı geriledi. Hastanede yatarken alınan kan kültürlerinde üreme olmadı. Tedavinin beşinci gününde hastaya ait kan örneği Ankara Ulusal Parazitoloji laboratuvarına moleküler çalışma için gönderildi. Gönderilen merkezde, insanda daha çok saptanan tür olan B. microti için primerler kullanılarak real time PCR ile B. microti varlığı (Qiagen) araştırıldı. B. microti zayıf pozitif olarak saptandı. Takiplerde problem gelişmeyen AST, ALT ve CRP değerleri normale gerileyen hasta yedi gün tedaviden sonra şifayla hastaneden taburcu edilmiş olup tedavi bitimi ve 15 gün sonrası periferik kan yaymalarının bakısında da eritrositlerde Babesia sp. etkenlerine rastlanmadı.

Şekil 1.

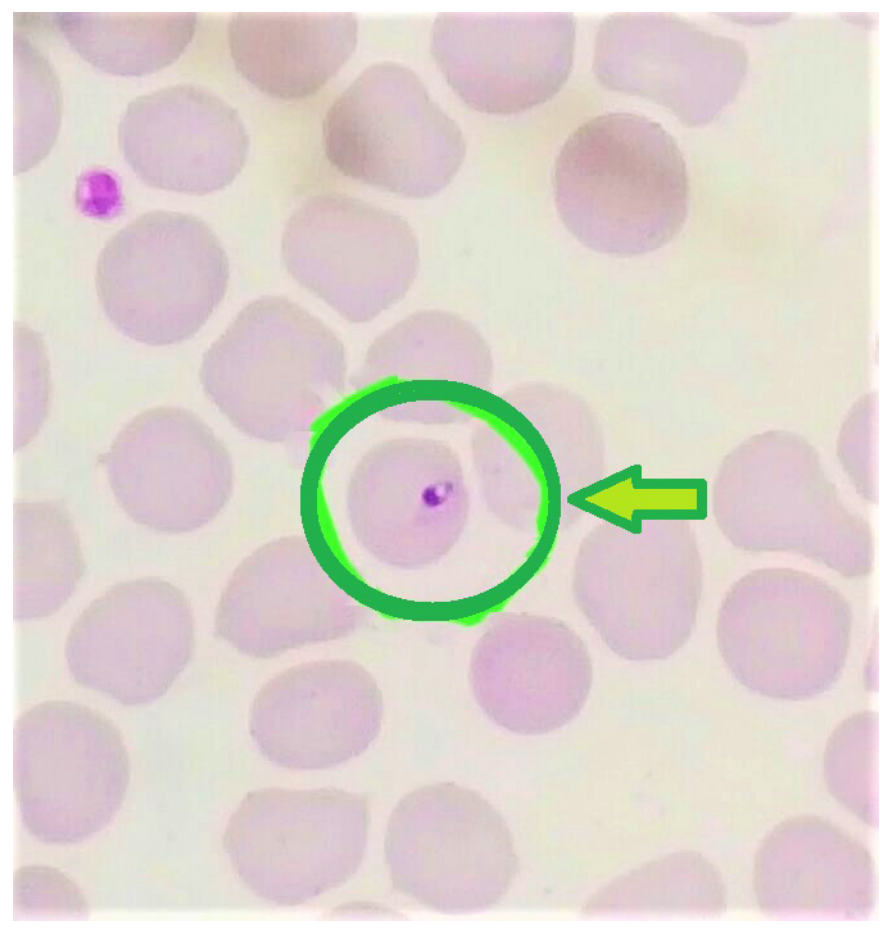

Genel Tip Derg 2021;31(2)182-184

183

\section{Tartışma}

Babesyozis önlenebilir ve tedavi edilebilir kene kaynaklı bir hastalıktır. Özellikle yaşl1, asplenik veya immünsüprese olan insanlarda şiddetli ve yaşamı tehdit edici olabilir (4) İnkübasyon süresi 1-3 haftadır. $\mathrm{Bu}$ sürede hastalarda halsizlik ve yorgunluk vardır. Akut hastalık aniden ortaya çıkar (10). Sonraki nonspesifik klinik sitma ile kolayca karışabilir. Şiddetli hemoliz nedeniyle oluşan sarılığa kalıcı, periyodik olmayan yüksek ateş $\left(40\right.$ ile $\left.41^{\circ} \mathrm{C}\right)$, titreme, yoğun terleme, baş ağrıs1, bel ağrısı ve karın ağrısı eşlik edebilir. Kusma ve ishal de olabilir (11). Laboratuvar bulgularında hemolitik anemi, trombositopeni ve karaciğer enzim yüksekliği görülebilir (12). Karaciğer orta derecede büyümüş ve ağrılı olabilir. Ağır vakalarda hastalarda intravasküler hemoliz ile oluşan böbrek yetmezliği ve pulmoner ödem ve bunların sonucunda şok benzeri semptomlar gelişir (11). Olguda ateş, baş ağrısı, üşüme, titreme, bulantı, ishal, karın ağrısı, hepatosplenomegali, pansitopeni ve karaciğer fonksiyon testi yüksekliği mevcut olup ikter yoktu. Hastada böbrek yetmezliği, pulmoner ödem ve şok benzeri semptomlar olmadığından ağır vaka olarak düşünülmedi.

Babesyozisin kesin teşhisi Giemsa veya Wright boyaması ile boyalı ince kan yaymasında eritrosit içi trofozoit veya merozoitin (klasik bulgu maltezin çapraz tetradı) görülmesi ile konur (2). Seroloji, tanıyı desteklemek veya doğrulamak için yararlıdır. Akut ve konvelesan durumlarda babesia IgG titresinde dört kat artış son infeksiyonu doğrularken, tek bir pozitif antikor titresi son infeksiyonu geçirilmiş infeksiyondan ayırt edemediğinden doğrulayıcı değildir. IFAT en sik uygulanan babesia serolojik testi olmakla birlikte EnzymeLinked Immuno Sorbent Assay (ELISA) ve Western Blot testi diğer serolojik yöntemlerdir $(13,14)$. IFAT ile serolojik tanı mümkün değildir. Çünkü spesifik antikorlar hastalık başladıktan en az 1 hafta sonrasına kadar saptanamaz. İnfeksiyon belirlendiğinde hasta ölmüş olabilir. Ancak, IFAT $B$. divergens' in neden olduğu insan olgularının Plasmodium falciparum, B. microti, 'den retrospektif olarak ayırt edilmesinde kullanılabilir $(15,10)$. Serum PCR'1 babesyozis tanısın koymada daha duyarlı bir yöntem olup Babesia türlerinin moleküler karakterizasyonunu sağladığından periferik kan yayması negatif olmasına rağmen infeksiyonu tespit edebilir $(16,17)$. Olguda tanı Giemsa boyası ile boyalı ince kan yaymasında eritrosit içi armut şeklinde merozoitin görülmesi ile konuldu. Tedavinin ancak beşinci gününde referans laboratuvara kan gönderilebildiğinden, real time PCR'da çalışılan B. microti testi zayıf pozitif olarak saptandı. Sonucun zayıf pozitif gelmesi hastaya ince kan yaymasında eritrosit içi merozoit görüldügünnde tedavinin başlanmış olması ve kanın geç gönderilebilmesi ile ilişkilendirildi. Ancak antikor tespiti referans laboratuvarda çalışılmadığı için kan örneği gönderilemedi.

Asemptomatik babesia infeksiyonu için tedavi gerekli değildir. Semptomatik kişiler en az 7-10 gün tedavi edilmelidir. Tedavide atovaquone ve azitromisin ya da ağır vakalarda kinin ve klindamisin kullanılabilir (2). Kinin (3x650 mg /gün) ve klindamisin (2x1.2 gr/ gün veya $3 \times 600 \mathrm{mg} /$ gün ağızdan) 1 hafta veya parazitemi remisyona girene kadar babesyozise yol açan tüm türlerin tedavisinde kullanılabilir (18). Semptomlar tedavi başladıktan bir veya iki gün içinde düzelmeye başlar. İnfeksiyonun vücuttan eradikasyonu üç ay içinde gerçekleşir (2). Sağlıklı bireyler tedavi edilmediğinde relaps nadir olarak gelişir (19). Babesyoziste persistans, relaps ve standart tedavi ile başarısızlık görülebilir. Bu durum B. microti veya $B$. divergens ile infekte kişilerde görülmektedir (20). Hastaya kinin (3x600 mg oral) ve klindamisin (4x600 mg parenteral) tedavisi verildi ve tedavinin ikinci gününde ateşi düştü ve pansitopenisi düzeldi.

Babesia ve plasmodiumun yayma görüntüsünün benzerliklerinden İnsan babesiozis olgusu - Kepenek Kurt et al. 
dolayı babesyozis; P. falciparum olarak yanlış tanı alabilir. Babesia spp. yuvarlak, oval veya armut şeklindedir ve kırmızı bir kromatin ile mavi sitoplazmaya sahiptir. Halka formları en yaygın olanıdır ve erken evre $P$. falciparum trofozoitlerin halkalarına benzeyebilir. Plasmodiumda hemozoin depozit pigmentinin (kahverengi pigment gibi görünür) bulunması ve muz şeklindeki gametositlerin varlığı ile Babesia'da tetradların varlığı (Malta haçı) iki tanıyı birbirinde ayırabilir. Babesyozisli hastalara sitma tedavisi verildiğinde hastalarda kronik infeksiyon ve persistan parazitemi ortaya çıkacaktır (2). Bu nedenle kene temas öyküsü olan, sıtma için yüksek endemik bölgede olup sitma benzeri şikayetlerle başvuran hastalarda babesyozis de ayırıcı tanıda düşünülmelidir.

Anamnezinde kene ve hayvan teması olmayan bu hastada ateş, pansitopeni olması sebebiyle öncelikle KKKA veya sitma düşünülmesine rağmen periferik kan ince yaymasında eritrosit içi babesiaların görülmesi ve buna yönelik başlanılan tedavinin ikinci gününde hastanın ateşinin düşmesi, pansitopeni tablosunun düzelmesi, KKKA PCR negatif gelmesi immunsupresif olmayan bu hastada babesyozisi desteklemektedir. Tedavinin ancak beşinci gününde referans laboratuvara PCR gönderilebilmiş olup $B$. microti pozitif gelmesi teşhisi doğrulamaktadır. Viral serolojik markerları negatif olan, tedavi esnasında karaciğer enzimleri artan hastanın enzim yüksekliği kininle ilişkilendirilmiş tedavi bittikten sonra hastanın karaciğer enzimleri ve CRP değeri normale gerilemiştir.

Sonuç olarak ateş, pansitopeni, karaciğer enzim yüksekliği nedeniyle başvuran immun kompetan hastalarda, kene ve hayvan teması olmasa da, periferik kan yaymasında eritrosit içi parazit saptandığında babesyozis de akla gelmeli ve buna yönelik ileri tetkik ve tedavi yapılmalidir.

\section{Kaynaklar}

1.Uilenberg G. Babesia -A historical overview. Vet Parasitol 2006;138:3-10.

2.Vannier E, Krause PJ. Human babesiosis. N Engl J Med 2012;366(25):2397-407.

3.Krause PJ. Babesiosis. Semin Pediatr Infect Dis 2000;11:182-8.

4.Vannier EG, Diuk-Wasser MA, Ben Mamoun C, Krause PJ. Babesiosis. Infect Dis Clin North Am 2015;29:357-370.

5.Poyraz O, Güneş T. Sinop Yöresinde Kırsal Kesimde Yasayan İnsanlarda Babesia microti Seroprevalans1. Türkiye Parazitol Derg 2010;34(2):81-5.

6.Kalkan K, Özçelik S, Malatyalı E. Sivas'ta insanlarda babesiozis seroprevalansının araştırılması. Cumhuriyet Tip Derg 2010; 32: 276-280.

7.İnci A, Çakmak A, Karaer Z, Dinçer Ş, Sayın F. Kayseri yöresinde sığırlarda babesiosis'in seroprevalans1. Turk J Vet Anim Sci 2002;26: 1345-1350.

8.Hildebrandt A, Gray JS, Hunfeld KP. Human babesiosis in Europe: what clinicians need to know. Infection 2013;41:1057-72.

9.Kavanaugh MJ, Decker CF. Babesiosis. Dis Mon 2012;3:55-60.

10.Telford SR, Gorenflot A, Brasseur P, et all. Babesial infections in humans and wildlife. Parasitic protozoa 1993; 1-45.

11.Gorenflot AK, Moubri E, Precigout, B. Carcy, and T. P. M. Schetters. Human babesiosis. Ann. Trop. Med. Parasitol. 1998.92:489-501.

12.Sanchez E, Vannier E, Wormser GP, Hu LT. Diagnosis, treatment, and prevention of lyme disease, human granulocytic anaplasmosis, and babesiosis: A Review. JAMA 2016;315(16):1767-77.

13.Krause PJ, Telford S, Ryan R, et al. Diagnosis of babesiosis: Evaluation of a serologic test for the detection of Babesia microti antibody. J Infect Dis. 1994; 169(4):923-6.

14.Levin AE, Williamson PC, Erwin JL, et al. Determination of Babesia microti seroprevalence in blood donor populations using an investigational enzyme immunoassay. Transfusion. 2014; 54(9):2237-44.

15.Homer, MJ, Aguilar-Delfin I. Telford SR 3rd, Krause PJ, Persing DH. Babesiosis. Clin. Microbiol. Rev. 2000.13(3):451-469.

16.Kjemtrup AM, Conrad PA: Human babesiosis: an emerging tick-borne disease. Int J Parasitol. 2000;30(12-13):1323-1337.

17.Krause PJ, Telford SR, Spielman A, et al. Comparison of PCR with blood smear and inoculation of small animals for diagnosis of Babesia microti parasitemia. J Clin Microbiol. 1996; 34(11):2791-4.

18.Diaz JH.Ticks, Including Tick Paralysis. In Mandell, Douglas, and Bennett's Principles and Practice of Infectious Diseases, 8th Edition, by Elsevier Saunders, 2015; 3266-3279 19.Moritz ED, Winton CS, Tonnetti L, et al. Screening for Babesia microti in the U.S Blood Supply. N Engl J Med. 2016; 375(23):2236-2245.

20.Simon MS, Westblade LF, Dziedziech A, et al. Clinical and molecular evidence of atovaquone and azithromycin resistance in relapsed Babesia microti infection associated İnsan babesiozis olgusu - Kepenek Kurt et al. with rituximab and chronic lymphocytic leukemia. Clin. Infect. Dis.2017;65(7):12221225 .

21.Ord RL, Lobo CA. Human babesiosis: pathogens, prevalence, diagnosis and treatment. Curr. Clin. Microbiol. Rep. 2015;2, 173-181.

22.Kavanaugh MJ, Decker CF: Babesiosis. Dis Mon 2012;58(6):355-360.

23.Göksu K. İnsanlarda rastlanan Babesia Enfeksiyonları. Mikrobiyoloji Bülteni(Babes 1888) $431-436$ 